\title{
PERAN GURU PENDIDIKAN AGAMA ISLAM DALAM MENINGKATKAN LITERASI DIGITAL SISWA SEBAGAI KECAKAPAN ABAD 21
}

\author{
Ahmad Muflihin 1) * \\ Toha Makhshun 2) \\ 1,2 Program Studi Pendidikan Agama Islam, \\ Universitas Islam Sultan Agung (UNISSULA), Semarang \\ *E-mail: a.muflihin@unissula.ac.id
}

\begin{abstract}
The purpose of this study is to analyze the amount of Islamic Education (PAI) teachers' efforts and roles, as well as how they should be involved in developing students' digital literacy. This is due to pupils' inadequate digital literacy, which manifests itself as an inability to process information gained via technology, information, and communication devices. In fact, digital literacy is one of the literacy foundations that are included in 21st century skills. According to data issued by the Ministry of Communication and Information, Indonesia ranks second in cyber crime and the frequency offalse information (hoax), making PAI teachers responsible for increasing digital literacy for students on both a moral and professional level. Interviews with various PAI teachers in Semarang are used in this study. The purpose of the interview was to evaluate how far PAI teachers had progressed in enhancing pupils' digital literacy. According to the findings of this study, PAI teachers' efforts are still minimal. The development of information technology as a method and a learning medium has not been optimized. As a result, enhancing digital literacy requires mutual awareness.
\end{abstract}

Keywords: Islamic Education Teacher, Digital Literacy, 21st Century Skills

\begin{abstract}
Abstrak
Penelitian ini bertujuan untuk mendiskusikan tentang sejauhmana upaya dan peran guru Pendidikan Agama Islam (PAI) dan bagaimana seharusnya dalam meningkatkan literasi digital siswa. Hal tersebut dilatarbelakangi oleh rendahnya tingkat literasi digital siswa berupa minimnya kemampuan dalam mengolah informasi yang didapatkan dari perangkat teknologi, informasi, dan komunikasi. Padahal, keterampilan literasi digital merupakan salah satu dari fondasi literasi yang termasuk dalam kecakapan abad 21. Data yang dirilis oleh kominfo bahwa Indonesia menduduki peringkat kedua dalam tindak kejahatan siber (cyber crime) dan maraknya informasi palsu (hoax), menjadikan guru PAI memiliki tanggung jawab secara moral dan profesional dalam meningkatkan literasi digital bagi para siswa. Metode penelitian ini menggunakan wawancara (interview) kepada beberapa guru PAI di kota Semarang. Wawancara tersebut dilakukan untuk melihat sejauhmana upaya yang dilakukan oleh guru PAI dalam meningkatkan literasi digital siswa. Hasil penelitian ini menunjukkan bahwa upaya yang dilakukan oleh guru PAI masih minim. Perkembangan teknologi informasi belum dioptimalkan sebagai sarana dan media pembelajaran. Sehingga dibutuhkan kesadaran bersama dalam hal peningkatan literasi digital.
\end{abstract}

Kata kunci: Guru Pendidikan Agama Islam, Literasi Digital, Kecakapan Abad 21 


\section{PENDAHULUAN}

Dalam dunia pendidikan, perubahan merupakan sebuah keniscayaan. Hal tersebut dikarenakan dunia berubah dan berkembang secara masif; dan dunia pendidikan harus sigap dalam meresponnya. Karena apabila dunia pendidikan tidak menyesuaikan dengan laju perubahan zaman, maka ia hanya akan menjadi sebuah menara gading yang tidak berarti yang tidak memberikan kontribusi dan bahkan justru menjadi penghambat dari sebuah dinamika proses kemajuan zaman.

Oleh karena itu sebenarnya tidak ada yang baku dari sebuah sistem pendidikan. Ia senantiasa berubah bukan hanya karena latah terhadap perubahan yang terjadi di sekitarnya, melainkan bagaimana seharusnya pendidikan menjadi pemegang kendali atas perubahan yang terjadi. Setiap perubahan yang terjadi di masyarakat haruslah diarahkan kepada kebaikan sehingga dapat memberikan manfaat bagi banyak orang; dan dunia pendidikan yang seyogyanya memikul tanggung jawab besar tersebut.

Berbicara tentang pendidikan maka ia tidak bisa terlepas dari sosok yang paling penting dalam menjalankan roda transformasi pengetahuan dan nilai tersebut, yaitu guru. Sebaik atau secanggih apapun sistem pendidikan yang telah dibangun, pada akhirnya gurulah yang menjalankan dan menerapkannya. Sehingga apabila kemampuan dan kemauan seorang guru tidak sejalan dengan sistem yang dibangun, maka pendidikan akan berjalan tanpa arah dan bahkan hanya berjalan di tempat.

Terlebih saat ini yang dikenal sebagai era disrupsi (Kasali, 2019) atau era revolusi industri 4.0 yang ditandai dengan meningkatnya konektivitas, interaksi, serta perkembangan dalam hal sistem digital, kecerdasan artifisial, dan virtual (Lase, 2019). Guru sebagai pemegang peranan paling penting dalam dunia pendidikan tentu harus meresponnya dengan sigap. Hal tersebut dikarenakan perubahan selalu membawa dua hal bersamanya, yaitu hal baik dan hal buruk. Gurulah yang harus mengarahkan dan memastikan para siswanya agar mampu memperoleh banyak hal baik dan terhindar sejauh mungkin dari hal buruk.

Kemajuan teknologi informasi digital harus diiringi dengan kemampuan literasi digital. Ini merupakan syarat mutlak yang tidak dapat diindahkan. Gerakan Literasi Sekolah yang digulirkan oleh Kemendikbud sejak Maret 2016, salah satu tujuannya adalah untuk merespon hal tersebut. Apalagi kecakapan abad 21 menuntut keterampilan literasi digital sebagai salah satu fondasi literasi (Kemendikbud, 2019). 
Minimnya tingkat literasi merupakan salah satu permasalahan yang harus segera diselesaikan. Hasil dari indeks Aktivitas Literas Membaca (Alibaca) Kemedikbud menunjukkan bahwa sembilan provinsi memiliki literasi tingkat sedang, 24 provinsi rendah, dan satu provinsi sangat rendah (Solihin et al., 2019). Untuk meningkatkan tingkat literasi tersebut, solusi yang ditawarkan oleh Lukman Solihin, peneliti di Pusat Penelitian Kebijakan Pendidikan dan Kebudayaan Balitbang Kemdikbud adalah melalui optimalisi pemanfaatan teknologi internet, yang kemudian dikenal dengan literasi digital (Hutapea, 2019). Hal tersebut dikarenakan jumlah pengguna internet yang semakin meningkat dari tahun ke tahun.

Survei yang dilakukan oleh Asosiasi Penyelenggara Jasa Internet Indonesia (APJII) menunjukkan bahwa pengguna internet Indonesia bertambah 10,12 persen pada 2018 dibandingkan tahun sebelumnya. Secara total, pengguna internet mencapai 171,17 juta pengguna dari populasi 264,16 juta jiwa (APJII, 2018). Artinya sebanyak $64,8 \%$ dari total populasi di Indonesia telah menggunakan internet. Sedangkan dari profil pengguna, sebanyak 71,8\% dari pelajar merupakan pengguna aktif internet.

Masih menurut hasil survei APJII, alasan paling utama penggunaan internet adalah sebagai komunikasi lewat pesan yaitu sebesar 24,7\% kemudian disusul media sosial sebesar 18,9\%. Sedangkan alasan kedua penggunaan internet adalah media sosial sebesar 19,1\% kemudian komunikasi lewat pesan sebesar 16,4\%. Data tersebut menunjukkan bahwa penggunaan internet didominasi dua hal, yaitu komunikasi dan media sosial. Hanya sedikit yang memanfaatkannya untuk mencari informasi atau data terkait sekolah yaitu sebesar 9,6\% (APJII, 2018).

Berdasarkan data-data di atas dapat diketahui bahwa, pertama teknologi informasi belum dimanfaatkan secara maksimal dalam hal pencarian informasi. Kedua, para pengguna teknologi informasi tersebut pun masih belum memiliki kemampuan (dan kemauan) untuk menelaah dan memverifikasi informasi yang diterimanya apakah valid atau hoax.

Literasi tidak hanya dipahami sebatas kemampuan membaca saja melainkan juga sampai pada tahap memahami (Harususilo, 2019). Dalam konteks literasi digital, tahapan sebelum proses memahami adalah memastikan atau memverifikasi tingkat validitas kebenaran dari sumber bacaan yang digunakan. Sebab dari banyaknya informasi yang beredar tidak semuanya merupakan informasi yang benar (valid). 
Di sinilah diperlukan peran dari seorang guru agar para siswanya mampu memanfaatkan kemajuan teknologi informasi ini semaksimal mungkin. Tidak terjebak dalam informasi palsu (hoax) apalagi turut serta menyebarkannya, dan bahkan hal yang paling mengerikan adalah mengalami apa yang disebut kejahatan siber (cyber crime). Guru Pendidikan Agama Islam (PAI) sebagai garda terdepan dalam pendidikan karakter dan sikap (spiritual), secara langsung maupun tidak langsung memiliki tanggung jawab moral dan profesional dalam meningkatkan literasi digital bagi para siswanya.

\section{METODE}

Penelitian ini menggunakan metode penelitian kualitatif. Data dikumpulkan melalui wawancara mendalam (in-depth interview) kepada Guru Pendidikan Agama Islam (PAI) di kota Semarang. Wawancara tersebut dilakukan untuk menggali informasi sejauhmana upaya yang telah dilakukan oleh para guru PAI dalam meningkatkan literasi digital siswa dan peran apa yang diambilnya. Data yang didapatkan dari hasil wawancara kemudian dianalisis berdasarkan teori peranan guru dan literasi digital.

\section{HASIL DAN PEMBAHASAN \\ Peran Guru Pendidikan Agama Islam}

Menurut UU Nomor 14 tahun 2005 tentang Guru dan Dosen, Guru adalah pendidik profesional dengan tugas utama mendidik, mengajar, membimbing, mengarahkan, melatih, menilai, dan mengevaluasi peserta didik pada pendidikan anak usia dini jalur pendidikan formal, pendidikan dasar, dan pendidikan menengah. Kedudukan guru sebagai tenaga profesional berfungsi untuk meningkatkan martabat dan peran guru sebagai agen pembelajaran untuk meningkatkan mutu pendidikan nasional (RI, 2019).

Berdasarkan undang-undang tersebut dapat diketahui bahwa menjadi guru profesional tidak hanya sebatas mengajar di dalam kelas saja. Guru -terutama Guru Pendidikan Agama Islam (PAI)- diharapkan mampu membimbing dan mengarahkan siswa untuk menjadi lebih baik terutama dari aspek sikap (afektif). Hal tersebut selaras dengan UU Sisdiknas yang menjelaskan tentang fungsi dari pendidikan nasional untuk mengembangkan potensi peserta didik agar menjadi manusia yang beriman dan 
bertakwa kepada Tuhan Yang Maha Esa, berakhlak mulia, sehat, berilmu, cakap, kreatif, mandiri, dan menjadi warga negara yang demokratis serta bertanggung jawab (P. Republik Indonesia, 2003).

Proses pembelajaran yang melibatkan interaksi antara siswa dan guru haruslah berjalan secara efektif. Guru harus mampu menempatkan posisi dan perannya di hadapan siswa. Bahkan puluhan tahun yang lalu, Ki Hajar Dewantara, yang juga dikenal sebagai bapak pendidikan Indonesia telah mengenalkan patrap triloka yang kemudian menjadi semboyan pendidikan di Indonesia; yaitu ing ngarso sung tulodo (di depan memberi teladan), ing madyo mangun karso (di tengah membangun kemauan), dan tut wuri handayani (dari belakang memberi dukungan). Patrap triloka tersebut merupakan prinsip dasar dari seorang guru terkait bagaimana seharusnya guru mampu menempatkan posisi ketika bersama dengan siswa sehingga terjalinlah interaksi atau hubungan timbal balik yang efektif antara guru dan siswa.

Ki Hajar Dewantara mengajarkan bahwa sebagai guru dalam kondisi tertentu harus berada di depan bagi para siswa dengan memberi teladan atau menjadi panutan, sehingga para siswa dapat mengikuti dan mencontoh secara langsung dari gurunya. Akan tetapi dalam kondisi tertentu pula, guru harus menempatkan dirinya berada di tengah atau di belakang bagi para siswa, yaitu ketika para siswa membutuhkan sosok yang memberikan motivasi dan dukungan.

Seiring perkembangan zaman, peran guru dalam proses pembelajaran semakin bervariatif. Dalam pengertian pendidikan secara luas, seorang guru seyogyanya berperan sebagai (Abin, 2003):

1. Konservator (pemelihara) sistem nilai yang merupakan sumber norma kedewasaan

2. Inovator (pengembang) sistem nilai ilmu pengetahuan

3. Transmitor (penerus) sistem-sistem nilai tersebut kepada peserta didik

4. Transformator (penerjemah) sistem-sistem nilai tersebut melalui penjelmaan dalam pribadi dan perilaku, dalam proses interaksi dengan sasaran didik

5. Organisator (penyelenggara) terciptanya proses edukatif yang dapat dipertanggungjawabkan, baik secara formal (kepada pihak yang mengangkat dan menugaskannya) maupun secara moral (kepada sasaran didik, serta Tuhan yang menciptakannya). 
Dari berbagai peranan di atas, diketahui bahwa guru diharapkan mampu menjadi sosok yang senantiasa membimbing para siswa/peseta didik agar mereka tetap berada dalam sistem nilai yang menjadi tujuan dari proses pendidikan. Dalam pendidikan agama, sesuai dengan PMA Nomor 16/2020 tentang Pengelolaan Pendidikan Agama di Sekolah tentang standar isi, bahwa sistem nilai yang dimaksud adalah pengetahuan dan wawasan keberagamaan peserta didik yang tercermin dalam menjadikan agama sebagai landasan akhlak mulia dan memiliki sikap mental agar bersikap jujur, amanah, disiplin, bekerja keras, mandiri, percaya diri, kompetitif, kooperatif, ikhlas, dan bertanggung jawab (K. A. Republik Indonesia, 2010).

Agar upaya pemeliharaan, pengembang, penerus, penerjemah, dan penyelenggara sistem nilai di atas dapat tercapai maka dibutuhkan kompetensi yang harus dikuasai oleh guru dalam melaksanakan tugas keprofesionalan. Kompetensi mendasar yang harus dikuasai tersebut adalah kompetensi kepribadian, kompetensi sosial, kompetensi pedagogik, dan kompetensi profesional. Kemudian bagi guru PAI ditambah dengan kompetensi kepemimpinan (K. A. Republik Indonesia, 2010).

Dalam PMA Nomor 16/2020 Pasal 16, kompetensi kepemimpinan yang harus dikuasai oleh Guru PAI meliputi (K. A. Republik Indonesia, 2010):

a. kemampuan membuat perencanaan pembudayaan pengamalan ajaran agama dan perilaku akhlak mulia pada komunitas sekolah sebagai bagian dari proses pembelajaran agama

b. kemampuan mengorganisasikan potensi unsur sekolah secara sistematis untuk mendukung pembudayaan pengamalan ajaran agama pada komunitas sekolah

c. kemampuan menjadi inovator, motivator, fasilitator, pembimbing dan konselor dalam pembudayaan pengamalan ajaran agama pada komunitas sekolah

d. kemampuan menjaga, mengendalikan, dan mengarahkan pembudayaan pengamalan ajaran agama pada komunitas sekolah dan menjaga keharmonisan hubungan antar pemeluk agama dalam bingkai Negara Kesatuan Republik Indonesia

Berbagai kemampuan yang harus dikuasai oleh guru PAI terkait kompetensi kepemimpinan di atas juga dapat dipahami sebagai peran yang harus dilakukan oleh guru PAI dalam proses pembelajaran. 


\section{Literasi Digital}

Konsep literasi digital mulai muncul sejak tahun 1990. Salah satu tokohnya, Gilster, mendefinisikan literasi digital sebagai suatu kemampuan untuk memahami dan menggunakan informasi dari berbagai sumber digital. Literasi digital tidak hanya mencakup kemampuan membaca saja, namun dibutuhkan pula suatu proses berpikir secara kritis untuk melakukan evaluasi terhadap informasi yang ditemukan melalui media digital (A'yuni, 2015). Gilster mengartikan literasi digital sebagai kemampuan memahami dan menggunakan informasi dalam banyak format dari berbagai sumber ketika itu disajikan di komputer (Pratiwi \& Pritanova, 2017).

Seiring dengan meningkatnya penggunaan media digital dan karena sifatnya yang bebas, tidak sedikit orang-orang yang menyalahgunakannya. Maraknya cyberbullying, penipuan, pelanggaran privasi, kecanduan, hingga penyebaran informasi palsu (hoax), menjadikan penggunaan media digital harus disertai dengan kehatihatian dan penuh kewaspadaan.

Penelitian yang dilakukan oleh Rianto, menujukkan bahwa masih banyak pengguna media digital yang tidak memiliki sifat kritis yang cukup atas sumbersumber informasi yang mereka akses sehingga menciptakan suatu pandangan yang bias dan menyesatkan. Dalam situasi semacam itu menurutnya suatu pemahaman literasi digital mutlak diperlukan (Rianto, 2017).

Beberapa pendekatan yang dapat digunakan sebagai pegangan dalam merencanakan konsep gerakan literasi digital, yaitu protectionist approach, creative media approach, social participation approach, critical analytical approach, dan media fun approach. Berbagai pendekatan tersebut digunakan sebagai acuan dalam melihat tingkat pemahaman literasi digital. Sehingga melalui pendekatan tersebut dapat diketahui apakah seseorang memiliki tingkat pemahaman literasi digital yang baik, yaitu apabila dia memiliki keterampilan, pengetahuan, dan pemahaman yang memungkinkan mereka untuk berpikir kritis, kreatif, cerdas dan aman saat bersentuhan dengan teknologi digital dalam kehidupan sehari-hari (Jordana \& Suwarto, 2018).

Penelitian tentang literasi digital telah menunjukkan perkembangannya di Indonesia. Terutama dengan dibentuknya berbagai komunitas literasi digital seperti: Komunitas Internet Baik, Japelidi (Jaringan Pegiat Literasi Digital), Siberkreasi, dan lain-lain. Bahkan Kemendikbud pun telah menginisiasi Gerakan Literasi Sekolah yang 
di dalamnya terdapat optimalisasi literasi digital sebagai fondasi literasi yang harus dikuasai.

\section{Kecakapan Abad 21}

Pendidikan Abad 21 merupakan pendidikan yang mengintegrasikan antara kecakapan pengetahuan, keterampilan, dan sikap, serta penguasaan terhadap TIK. Kecakapan tersebut dikembangkan melalui berbagai model pembelajaran melalui kegiatan yang sesuai dengan karakteristik kompetensi dan materi pembelajaran. Oleh karena itu, pada abad 21 ini seseorang baik itu pendidik maupun peserta didik harus memiliki keterampilan 4 C. Keterampilan 4 C merupakan singkatan dari Critical Thinking (berpikir kritis), Collaboration (kemampuan bekerja sama dengan baik), Communication (kemampuan berkomunikasi), dan Creativity and Innovation (kreatifitas dan inovasi) (Kemdikbud, 2017).

UNESCO memberikan empat pilar pendidikan yang terdiri atas learning to know, learning to do, learning to be, dan learning to live together in peace. Tetapi untuk mencapai Tujuan Pendidikan Nasional, tidak cukup dengan empat pilar tersebut, maka dalam pendidikan di Indonesia ditambah dengan dengan pilar pendidikan "Belajar untuk memperkuat keimanan, ketakwaan, dan akhlak mulia” (Kemdikbud, 2017).

\section{Peningkatan Literasi Digital Siswa oleh Guru PAI}

Secara konseptual, peran guru PAI dalam meningkatkan literasi siswa dapat dilihat dalam aspek kompetensi kepemimpinan yang harus dikuasai. Guru harus menjaga, mengendalikan, dan mengarahkan pembudayaan pengamalan ajaran agama ketika bersentuhan dengan teknologi. Akan tetapi permasalahan yang muncul di lapangan tentu tidak sesederhana yang dibayangkan.

Muhammad Salim, guru PAI di tingkat menengah pertama, menjelaskan bahwa minimnya sarana masih menjadi kendala utama dalam proses pembelajaran berbasis literasi digital. Ketiadaan kepemilikan smartphone sehingga harus bergantian menggunakan, dan jumlah kuota internet yang dimiliki baru sebatas mencukupi untuk memanfaatkan internet sebagai sarana komunikasi. Walhasil beberapa siswa merasa keberatan apabila diminta untuk mengakses media yang menghabiskan banyak kuota seperti YouTube. Kendala serupa juga dialami oleh guru PAI lainnya, Jamaludin, ia menjelaskan bahwa sinyal menjadi penghalang bagi para siswa untuk mengunduh informasi dari internet. Ketika pembelajaran dilakukan secara daring melalui zoom, 
metode yang digunakan masih berupa ceramah dengan memberikan tugas sebanyak satu atau dua kali dalam sebulan.

Sedangkan Ahmad Khidir, mulai mencoba untuk memproduksi media dalam proses pembelajarannya, yaitu dengan membuat video penjelasan tentang materi pembelajarannya. Para siswa pun diberi tugas untuk membuat video agar melatih kemampuan berkomunikasinya. Kemudian kendala lain yang dirasakan oleh I'anaratul Huday yaitu ketika menjelaskan materi tentang akhlak. Ia merasa kesulitan ketika harus mencontohkan akhlak dan juga memantau perkembangan karakter atau akhlak para siswanya.

Dari berbagai wawancara yang dilakukan kepada beberapa guru PAI di kota Semarang, hampir sebagiaan besar menggunakan media grup whatsApp sebagai sarana berdiskusi. M. Alif Faiq Anidzom menambahkan bahwa metode diskusi dan tanya jawab di grup digemari oleh para siswa dikarenakan bisa sekaligus bersenda gurau dan berinteraksi secara langsung dengan teman-teman yang lain.

Beberapa proses pembelajaran yang terekam dari hasil wawancara, menunjukkan bahwa guru masih menjadi sumber belajar. Guru memberikan materi, berdiskusi/tanya jawab, kemudian diakhiri dengan pemberian tugas. Pola yang digunakan dalam proses pembelajaran masih sama halnya dengan pembelajaran konvensional, hanya medianya saja yang berubah.

Kompetensi literasi digital yang harus dikuasai oleh siswa adalah sebagaimana yang telah ditetapkan oleh Kemendikbud melalui Gerakan Literasi Sekolah (GLS) yang dicanangkannya.

\begin{tabular}{|l|l|l|l|}
\hline \multicolumn{1}{|c|}{ JENJANG } & KOMUNIKASI & BERPIKIR KRITIS & $\begin{array}{c}\text { KEAMANAN MEDIA } \\
\text { (MIEDIA SAFETY }\end{array}$ \\
\hline $\begin{array}{l}\text { SD/SDLB kelas } \\
\text { rendah }\end{array}$ & $\begin{array}{l}\text { Mengartikulasikan } \\
\text { empati terhadap } \\
\text { tokoh cerita }\end{array}$ & $\begin{array}{l}\text { Memisahkan fakta } \\
\text { dan fiksi }\end{array}$ & $\begin{array}{l}\text { Mampu menggunakan } \\
\text { teknologi dengan } \\
\text { bantuan/pendampingan } \\
\text { orang dewasa }\end{array}$ \\
\hline $\begin{array}{l}\text { SD/SDLB } \\
\text { Kelas tinggi }\end{array}$ & $\begin{array}{l}\text { Mempresentasikan } \\
\text { cerita dengan } \\
\text { efektif }\end{array}$ & $\begin{array}{l}\text { Mengetahui jenis } \\
\text { tulisan dalam } \\
\text { media dan } \\
\text { tujuannya }\end{array}$ & $\begin{array}{l}\text { Mengetahui batasan } \\
\text { unsur dan aturan } \\
\text { kegiatan sesuai konten }\end{array}$ \\
\hline SMP/SMPLB & $\begin{array}{l}\text { Bekerja dalam tim. } \\
\text { mendiskusikan } \\
\text { informasi dalam } \\
\text { media }\end{array}$ & $\begin{array}{l}\text { Menganalisis dan } \\
\text { mengelola } \\
\text { informasi dan } \\
\text { memahami } \\
\text { relevansinya }\end{array}$ & $\begin{array}{l}\text { Memahami etika dalam } \\
\text { menggunakan } \\
\text { teknologi dan media } \\
\text { sosia }\end{array}$ \\
\hline $\begin{array}{l}\text { SMA/SMK/ } \\
\text { SMALB }\end{array}$ & $\begin{array}{l}\text { Mempresentasikan } \\
\text { analisis dan } \\
\text { mendiskusikannya }\end{array}$ & $\begin{array}{l}\text { Menganalisis } \\
\text { stereotip/ideologi } \\
\text { dalam media }\end{array}$ & $\begin{array}{l}\text { Memahami landasan } \\
\text { etika dan } \\
\text { hukum/aturan } \\
\text { teknologi }\end{array}$ \\
\hline
\end{tabular}

Peta Kompetensi Literasi Sekolah (Kemendikbud, 2019) 
Dalam upaya meningkatkan literasi digital, sebagai langkah awal ada baiknya siswa mulai diajarkan untuk memperoleh informasi melalui internet yang terkait dengan materi pelajaran. Peran guru tidak lagi menjadi satu-satunya sumber belajar melainkan pembimbing, yaitu membimbing para siswanya untuk memaksimalkan teknologi sebagai sumber informasi. Selain itu guru juga menjadi verifikator/validator yaitu membantu para siswanya untuk memverifikasi informasi yang diperolehnya apakah valid atau tidak, apakah sumber informasi yang digunakannya layak dan kredibel untuk dijadikan sebagai rujukan.

Dua peran guru PAI sebagai pembimbing dan verifikator/validator inilah yang menurut hemat penulis harus mulai dikuasai dan diterapkan. Sebagai pembimbing juga artinya guru membersamai siswa ketika mengolah informasi. Sedangkan sebagai verifikator/validator artinya guru tetap dan selalu mengawasi para siswa dan memberikan nasehat apabila diperlukan. Dua peran ini sejalan dengan apa yang disebut oleh Ki Hajar Dewantara yaitu ing madyo mangun karso.

Sedangkan mekanisme pembimbingan dalam meningkatkan literasi digital siswa oleh guru PAI dapat dilakukan secara bertahap sebagai berikut:

1. Memberikan pemahaman terkait perlindungan data pribadi

Siswa hendaknya diajarkan bahwa privasi merupakan hal yang penting. Tidak semuanya boleh dibagikan di media sosial. Sebab apabila tidak berhati-hati maka data yang kita miliki dapat disalahgunakan oleh orang lain yang tidak bertanggung jawab.

2. Menekankan pentingnya tata krama dan etika

Siswa diberikan pengertian bahwa internet bukanlah ruang hampa. Internet atau yang biasa disebut dunia maya saat ini telah menjadi bagian dari dunia nyata. Maka, dalam berinteraksi dengan orang lain di dunia maya pun harus menggunakan tata krama dan etika sebagaimana halnya di dunia nyata.

3. Mengarahkan kepada sumber informasi yang kredibel dan cara menghindari berita palsu (hoax)

Dunia digital telah menjadi bak lautan informasi yang sangat mudah dimasuki oleh siapa saja dan kapan saja. Semua informasi yang dibutuhkan banyak tersedia di sana. Akan tetapi harus dipahami juga bahwa tidak semua informasi menyampaikan kebenaran. Kemudahan akses dan juga kemudahan memproduksi 
informasi menjadikan informasi yang tersebar tidak dapat dipercayai begitu saja. Informasi tersebut harus dicek terlebih dahulu kebenarannya. Oleh karena itu guru PAI hendaknya memberikan pengetahuan mendasar tentang sumber-sumber yang dapat dipercayai dan dapat dijadikan sebagai referensi.

4. Memprioritaskan aspek kebermanfaatan

Tersebarnya beragam informasi di internet menjadikan para penggunanya mampu bertahan selama berjam-jam, dan tidak jarang yang dilakukan adalah halhal yang kurang bermanfaat. Guru PAI harus menyadarkan siswa agar tidak disibukkan oleh hal-hal yang tidak memberikan faedah. Istilah FOMO (fear of missing out) yang banyak dialami oleh anak muda harus dipahami bahwa tidak semua hal harus diketahui dan diikuti.

5. Menjaga keharmonisan

Maraknya perundungan (cyber bullying) di kalangan anak muda terjadi dikarenakan minimnya kesadaran tentang pentingnya sikap saling menghargai. Ada kalanya ketika seseorang menyampaikan sesuatu yang berlainan paham maka tidak segan-segan orang lain langsung memberikan komentar yang tidak pantas. Dunia digital adalah dunia yang sangat luas dan ia tidak lagi dibatasi oleh sekatsekat layaknya sebuah negara. Oleh karena itu, perbedaan pendapat dan pemahaman adalah hal yang lumrah dikarenakan perbedaan ideologi dan budaya. Akan tetapi perbedaan tersebut menjadi tidak lumrah apabila disikapi dengan melakukan perundungan.

\section{SIMPULAN DAN SARAN}

\section{Simpulan}

Realitas yang terjadi di lapangan menunjukkan bahwa perkembangan teknologi informasi belum diimbangi dengan upaya untuk memaksimalkannya sebagai sarana pembelajaran. Peningkatan sarana dan prasarana yang memadai seperti pengadaan smartphone, sinyal, dan kuota internet merupakan tantangan bagi pemerintah yang harus segera dicarikan solusinya. Sedangkan pemahaman bahwa diperlukan berbagai upaya untuk meningkatkan tingkat literasi digital siswa harus mulai disadari oleh guru PAI. Guru tidak lagi menjadi satu-satunya sumber belajar, melainkan sebagai pembimbing dan validator/verifikator. Sedangakan upaya yang dapat dilakukan oleh guru PAI secara bertahap dapat berupa: a) memberikan pemahaman terkait 
perlindungan data pribadi, b) menekankan pentingnya tata krama dan etika, c) mengarahkan kepada sumber informasi yang kredibel dan cara menghindari berita palsu, d) memprioritaskan aspek kebermanfaatan, dan e) menjaga keharmonisan.

\section{Saran}

Seiring dengan perkembangan zaman, guru PAI harus memperluas sudut pandangnya terkait peran yang perlu diambil dalam melakukan proses pendidikan kepada para siswanya. Proses pembelajaran yang terjadi saat ini tidak hanya dapat dilakukan di dalam ruang kelas melainkan dapat dilakukan tanpa batas. Oleh karena itu tugas guru PAI bukan untuk melarang para siswanya mendapatkan ilmu dari luar kelas melainkan justru memfasilitasi dan membimbing para siswa agar mampu memaksimalkan perkembangan teknologi informasi sebagai sarana memperoleh ilmu pengetahuan dengan tetap memegang nilai-nilai keagamaan.

\section{DAFTAR PUSTAKA}

A'yuni, Q. Q. (2015). Literasi digital remaja di kota surabaya. Libri-Net.

Abin, S. M. (2003). Psikologi Pendidikan. Bandung: Remaja Rosdakarya.

APJII, A. P. J. I. I. (2018). Laporan Survei Penetrasi dan Profil Perilaku Pengguna Internet Indonesia 2018. APJII. https://www.apjii.or.id/survei

Harususilo, Y. E. (2019). FLS 2019: Saatnya Penguatan Literasi Tingkat Tinggi dan Digital!

Kompas.Com. https://edukasi.kompas.com/read/2019/07/26/19163511/fls-2019-saatnyapenguatan-literasi-tingkat-tinggi-dan-digital?page=all\#page 2

Hutapea, E. (2019). Dapatkah Internet Jadi Solusi Meningkatkan Literasi Indonesia? Kompas.Com. https://edukasi.kompas.com/read/2019/06/23/07112161/dapatkahinternet-jadi-solusi-meningkatkan-literasi-indonesia?page=all\#page2

Jordana, T. A., \& Suwarto, D. H. (2018). Pemetaan Gerakan Literasi Digital di Lingkup

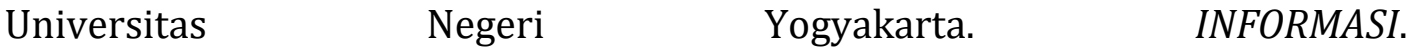
https://doi.org/10.21831/informasi.v47i2.15735

Kasali, R. (2019). Disruption" Tak ada yang tak bisa diubah sebelum dihadapi motvasi saja tidak cukup".

Kemdikbud. (2017). Implementasi Pengembangan Kecakapan Abad 21 dalam Perencanaan Pelaksanaan Pembelajaran (RPP). In Direktorat Jenderal Pendidikan Dasar dan Menengah. 
Kemendikbud, S. G. L. S. (2019). Desain Induk Gerakan Literasi Sekolah (Cetakan II). Direktorat Jenderal Pendidikan Dasar dan Menengah Kementerian Pendidikan dan Kebudayaan.

Lase, D. (2019). Pendidikan di era revolusi industri 4.0. SUNDERMANN: Jurnal Ilmiah Teologi, Pendidikan, Sains, Humaniora Dan Kebudayaan, 12(2), 28-43.

Pratiwi, N., \& Pritanova, N. (2017). PENGARUH LITERASI DIGITAL TERHADAP PSIKOLOGIS ANAK DAN REMAJA. Semantik. https://doi.org/10.22460/semantik.v6i1p11-24.250

Republik Indonesia, K. A. (2010). Peraturan Menteri Agama Nomor 16 Tahun 2010 tentang Pengelolaan Pendidikan Agama pada Sekolah.

Republik Indonesia, P. (2003). Undang-undang Republik Indonesia nomor 20 tahun 2003 tentang sistem pendidikan nasional. Jakarta: Pemerintah Republik Indonesia.

RI, K. P. N. (2019). Undang-Undang RI No. 14 Tahun 2005 Tentang Guru dan Dosen.

Rianto, P. (2017). MEDIA BARU, VISI KHALAYAK AKTIF DAN URGENSI LITERASI MEDIA. Jurnal Komunikasi Ikatan Sarjana Komunikasi Indonesia. https://doi.org/10.25008/jkiski.v1i2.54

Solihin, L., Utama, B., Pratiwi, I., \& Novirina. (2019). Indeks Aktifitas Literasi Membaca 34 Provinsi. Pusat Penelitian dan Kebijakan Pendidikan dan Kebudayaan, Badan Penelitian dan Pengembangan, Kementerian Pendididkan dan Kebudayaan. http://repositori.kemdikbud.go.id/13033/1/Puslitjakdikbud_Indeks Aktivitas Literasi Membaca 34 Provinsi 